\title{
MANAGEMENT PRACTICE AND KIRK SESSIONS: \\ AN EXPLORATION OF THE SCOTTISH \\ CONTRIBUTION TO MANAGEMENT
}

\section{ALISTAIR MUTCH}

In 1866 Andrew Barclay Walker, brewer and public house owner, took up a $\mathcal{E}^{25}$ share in St Andrew's Church of Scotland, Rodney Street, Liverpool and joined the Committee of Management. ${ }^{1} \mathrm{He}$ was to become Mayor of the city on two occasions and gift the Walker Art Gallery to the city. His wealth, expressed in his purchase of a Derbyshire estate, his steam yacht and his second marriage into aristocratic circles, was derived from a very distinctive business practice. This was the direct management, as opposed to the tenancy, of public houses. This practice, in turn, required the construction of both a managerial hierarchy and elaborate systems to facilitate detailed accountability. The nature of these innovations is explored further below, but their interest extends beyond the confines of Liverpool or the history of brewing. They raise questions about the origin of innovations in management practice and, taken in conjunction with other examples, suggest that there may have been a distinctively Scottish contribution. The suggestion which is raised and pursued in this essay is that religious organisational practice, based on the particular ecclesiastical polity of Scottish Presbyterianism and embodied in the routines of the kirk session, may have contributed to a distinctive focus on managerial accountability. Christopher Whatley has argued that "before the end of the eighteenth century, and increasingly so in the nineteenth, Scots - who had hitherto been drawing hard on English (and other) expertise - were making contributions to the industrialisation process in England and Ireland and on the continent of Europe'. ${ }^{2}$ It is the contention of this essay that one such contribution may have been in the domain of management.

Management is, frankly, a rather mundane matter; it cannot compete with the

(D)erbyshire (R)ecord (O)ffice, D1849 Box 2 bundle 19 'miscellaneous', Share certificate, St Andrew's Church, 15 Dec. 1866; for Walker's regular attendance, (L)iverpool (R)ecord (O)ffice 380PWK/1/8 Appendix A Bundle 11 in-letters 1890,10 Mar. 1890, A. Wilson, Chester.

2 Christopher Whatley, Scottish Society 1707-1830: Beyond Jacobitism, Towards Industrialisation (Manchester, 2000), p. 3. 
bigger historical dramas. Perhaps this is why its development plays only a minor if any part in accounts of the bigger changes that came over Scotland in the late eighteenth and early nineteenth centuries. The development of management plays no part in either popular or more academic accounts of the Scottish Enlightenment. ${ }^{3}$ It is not that the importance of management as part of the industrialisation process goes unacknowledged. Whatley, for example, recognises that what he terms 'two serious and interconnected problems' hampered development of the Scottish economy in the eighteenth century. One was the control of labour; the second was that of 'managing sizeable organisations'. The key problem here was that of 'middle management', but this attracts only a single paragraph, as against several pages on the problems of labour control. There is a twin problem here: the invisibility of much management activity in the archives and the invisibility of their importance in the eyes of many historians. However, a full understanding of the development of modern industrial society demands some attention to the roots of management.

One area in which this debate has occurred is in the history of management in the United States. It is briefly reprised in William Roy's account of the development of the industrial corporation. ${ }^{5}$ The traditional view, based on the pioneering work of Alfred Chandler, is that management was the rational response to the technical and organisational demands of the railroads. With their need for precise operation to laid down timetables, these required tight discipline overseen by a management hierarchy with clearly defined roles and responsibilities. Hierarchy is therefore a natural product of economic pressures. By contrast, Roy, operating in the 'institutionalist' perspective of organisational analysis, argues that Chandler underplays the influence of military models in providing ready made models of how to organise large scale enterprise. He is drawing here on an institutionalist argument which points to the embedding of commercial enterprises in a social and cultural context, in which they face pressures not only to be economically efficient but also to be legitimate organisations when measured against the prevailing norms. ${ }^{6} \mathrm{~A}$ particularly important time, in this perspective, is the moment of organisational birth, in which existing models can be drawn upon and adapted to meet new circumstances. ${ }^{7}$ One such existing model might be that of religious organisation. That this is an unusual claim can be seen in Pollard's classic study of The Genesis of Modern Management - or rather, can be surmised from

${ }^{3}$ Arthur Herman, The Scottish Enlightentment: The Scots' Invention of the Modern World (London, 2001); Alexander Broadie (ed.), The Cambridge Companion to the Scottish Enlightenment (Cambridge 2003).

${ }^{+}$Whatley, Scottish Society, p. 81.

5 William G. Roy, Socializing Capital: The Rise of the Large Industrial Corporation in America (Princeton, 1997), p. 292.

${ }^{6}$ Walter W. Powell and Paul J. DiMaggio, The New Institutionalism in Organisational Analysis (Chicago, 1991).

Arthur Stinchcombe, 'Social Structure and Organisations', in James G. March (ed.), Handbook of Organisations (Chicago, 1965), pp. 142-93. 
the absence of this as a possible model. ${ }^{8}$ Rather, the attention here is on the landed estate and mercantile practice, both of which are found wanting. One argument that will be pursued in this essay is the possibility that Pollard was drawing on English religious practice and that such practice would indeed not be a fertile source of ideas. However, the contention is that if we look at Scottish, and specifically Presbyterian, religious organisational practice then we do indeed find some intriguing potential sources of managerial practice.

This would appear to be a novel claim and so requires that we consider briefly the relationship between religion and business and how it has been handled by historians. Of course, the classic debate is that over the relationship between particular forms of Protestantism and the 'spirit' of capitalism. Whatley reviews the evidence for this in the eighteenth century briefly and exhibits a degree of scepticism. For him of more importance are the ways in which the church formed a means of engendering labour discipline. ${ }^{9}$ The most sustained treatment, of course, is that supplied by Gordon Marshall for an earlier period. His argument is that 'It seems the case that the two belief-systems are not only strikingly consistent with one another, but actually related'. ${ }^{10}$ Brown, however remains unconvinced, suggesting that evidence of such relationships is tenuous at best. ${ }^{11}$ The problem is that it is feasible to find examples of ideas that would indeed foster attitudes conducive to capitalist enterprise, and that it is also possible to find examples of business practice that fit religious strictures, but not so easy to demonstrate the link between the two. Because of this the focus in much of the work on the relationship between religion and business has turned to focus on the characteristics of business leaders. Such research, argues Brown, 'shows no substantive difference in extent between Scotland and the rest of Britain, and seems unable to show how denominational or doctrinal affiliations influenced entrepreneurship or the conduct of business'. ${ }^{2}$ A line of argument that is not pursued in these inquiries is that particular religious practices might foster concomitant management practices. To the extent that religious practice has been examined it has been in tracing how a shared religion could provide networks of trust at a time when institutions regulating credit were fragile. So, for example, the Quaker system of regional meetings provided regular opportunities for the maintenance and policing of trust relations in a network of Friends. ${ }^{13}$ However, what is suggested in this essay is that the influence of organisational practices based on religious tenets might go further into directly influencing managerial practices.

\footnotetext{
8 Sidney Pollard, The Genesis of Modern Management (1965).

"Whatley, Scottish Societ $\gamma$, p. 99.

${ }^{10}$ Gordon Marshall, Presbyteries and profits: Calvinism and the development of capitalism in Scotland, 1560-1707 (Oxford, 1980), p. 235.

11 Callum G. Brown, Religion and Society in Scotland since 1707 (Edinburgh, 1997), p. 178.

12 Brown, Religion and Society, p. 179.

13 Ann Prior and Maurice Kirby,'The Society of Friends and the Family Firm, 1700-1830', Business History, vol. 35, no. 4. (1993), pp. 66-85.
} 
This notion is built in part on the influence of other work shaped by a broadly institutionalist perspective. The important focus in this work is on the significance of practice. In this fashion, what is important is the seemingly mundane. Frequently repeated practice becomes accepted as the taken for granted way of behaving and becomes available for transfer into other domains of activity. In a sociological account of the formation of certain key figures of the Scottish Enlightenment, for example, Camic has argued for the need to look at certain shared experiences. In this such seemingly mundane matters as the organisation of teaching are argued to have contributed to the shaping of a particular way of looking at the world. ${ }^{14}$ In a similar vein, Muldrew's account of the development of institutions for credit in England over the period 1550 to 1720 depends on a detailed examination of mundane practices..$^{15}$ It was the experience of litigation over debt, he argues, reaching as it did virtually every household from the 1580s, that led to changes in both institutions and ideas. What this suggests is that there may be value in exploring the distinctive organisational practices that were called forth by the particular form that the Scottish variation of Presbyterianism took in particular, the operation of elders in kirk sessions. Such practices may, it is argued, have formed a resource on which some Scottish entrepreneurs drew in their creation of innovative managerial practices. Of particular interest here is the creation of managerial hierarchies rendered accountable through careful attention to precise record keeping. Before exploring some examples which suggest this avenue for inquiry, it is worth sounding some initial notes of caution. We have to be aware here of the speculative nature of what is being argued and the lack of work in this area.The archive-based material that will be presented is only offered as illustration, rather than as a comprehensive account. In particular, when comparative material on the English experience is presented it needs to be appreciated that hardly any work has been done here. For both periods the relevant work is much earlier, with a particular focus on the seventeenth century. This is helpful and suggestive, but much more work needs to be carried out on the eighteenth century. In this sense, this essay is suggesting potential avenues for such research. It is also not being suggested that modern management was shaped only or primarily by the Scottish experience. The development of modern management is clearly a multi-factorial process that cries out for further work. What is being suggested, however, is that management, as with any human activity, is profoundly shaped by the cultural and social context from which it originates With this in mind, it is interesting to explore the extent to which religious practice, and in particular the organisational practice of particular religious forms, conditioned and influenced the development of specific managerial practices. In order to conduct such an exploration, we have first to explain what these specific managerial practices were.

${ }^{14}$ C. Camic, Experience and Enlightenment: Socialization for Cultural Change in Eighteenth-Century' Scotland (Chicago, 1983).

${ }^{15}$ Craig Muldrew, The Econony of Obligation: The Culture of Credit and Social Relations in Early Modern England (Basingstoke, 1998). 


\section{Managers and accountability: some examples}

In 1846 Andrew Barclay Walker was granted a licence for a public house on Brownlow Hill. ${ }^{16}$ His father, Peter, variously brewer, inventor (credited with devising the famous Burton Union system of brewing) and coal owner in Ayrshire had moved to Liverpool at some point in the decade. ${ }^{17}$ He had entered into partnership with another expatriate Scot, the brewer Alexander Morrison. ${ }^{18}$ However, by 1851 he was brewing with Andrew in Warrington and the name of Peter Walker \& Son became a familiar one in Liverpool. It was Andrew who appears to have been the force behind the business, and particularly behind the retailing side in Liverpool. In 1851 he took over the management of the Coperas Hill Vaults for his uncles David and Robert. David and Robert were colliery managers in St Helens, with David managing Andrew's colliery interests there. ${ }^{19}$ The direct management of public houses may have arisen from this reciprocal family arrangement. In the following year Andrew acquired vaults at Byrom Street, in 1854 in Fox Street, in 1855 in London Road and in 1856 in Soho Street. All these properties were run as managed houses, as opposed to being tenanted. They sold beer from Peter Walker \& Son, brewed at Warrington, and wines and spirits from Andrew Barclay Walker \& Co. ${ }^{20}$ It would seem that the running of these houses under direct management might have been partly as a result of Andrew drawing on family experience in the coal business, partly as a contingent response to his uncles' trust in his competence and partly a response to conditions in the town. ${ }^{21}$ The company was later to claim that it was the originator of the 'managerial system'.2 This development, at a time when most brewers owned few, if any, public houses, and ran those which they did own under tenancy, was a distinctive one. ${ }^{23}$

Andrew's ownership of public houses progressed steadily, with ten being under his control by 1865 , and thirty-four by 1875 . By the end of the 1870 s he had fifty-one houses under direct management, carefully recorded in the extensive ledgers which mark his activities, both personal and business. ${ }^{2+}$ These records are

${ }^{16}$ LRO 347 JUS Licensing Registers $1 / 1 / 3$ 1845-6.

17 P. Moynihan, 'Walkers Ales', Journal of the Brewery History Society, vol. 46 (1985), pp. 3-8; vol. 47 (1986), pp. 9-16.

${ }^{18}$ Mc Corquodale's Annual Liverpool Directory (Liverpool, 1848), p. 265; Core's Directory of Liverpool and Environs (Liverpool, 1849), p. 411.

${ }^{19}$ T. C. Barker and J. R. Harris, A Merseyside Town in the Industrial Revolution: St Helens 1750-1900, (1959), p. 341; LRO PWK380/1/4/13 bill from Thomas Haddock, solicitors, 1860, 'Several attendances on Mr D. Walker on this and previous days conferring on your colliery affairs.'

${ }^{20}$ Alistair Mutch, 'Public houses as multiple retailing: Peter Walker \& Son 1846-1914', Busimess History, forthcoming.

21 Alistair Mutch,'Magistrates and Public House Managers, 1840-1914:Another Case of Liverpool Exceptionalism?’, Northern History, vol. 40, no. 2 (2003), pp. 325-42.

22 Peter Walker \& Son, Walker's Warrington Ales (Warrington, 1896).

23 Alistair Mutch, 'Shaping the public house 1850-1950: business strategies, state regulation and social history', Cultural and Social History, vol. 1, no. 2 (2004), pp. 179-200.

${ }^{24}$ DRO Walker-Okeover Papers, D1849, 5/1 Andrew Barclay Walker journal 1852-84. 
fragmentary, so it is not possible to be exact about the extent of his estate or to be precise about how it was run, but we can draw some conclusions from that which survives. One is that he built up a managerial hierarchy, based on a number of key trusted figures. One of these was John Price, who first appears as 'one of the Clerks of the firm of Peter Walker \& Son in which I am a partner' and the recipient of a legacy of $£ 300$ in Walker's will of $1870 .^{25}$ By 1880 he was noted as the General Manager and by 1883 he attained the status of executor. ${ }^{26}$ For 1873 a report survives in which he writes to Walker enclosing 'an account of the weeks sales showing an improvement, a statement respecting the Vaults, which may be interesting, and a statement of A B W. \& Co's affairs which I am afraid will not be very satisfactory' ${ }^{27}$ Unfortunately the vaults' statement has not survived, but this evidence suggests a detailed monitoring of business progress. This is supported by the survival of annual profit and loss accounts for each public house for a number of years. ${ }^{28}$ These accounts are fragmentary and scattered amongst both business and personal papers, but their existence suggests a focus on the detailed monitoring of managerial activity in the pubs made possible by an elaborate accounting system and embodied in a managerial hierarchy involving house inspectors at the lowest level reporting to the head of a dedicated Managed House Department. ${ }^{29}$

These practices were widely adopted in Liverpool, with a majority of the city's public houses being directly managed by the 1890s. This was in sharp contrast to practice elsewhere in England, with the exception of Birmingham, where public house management was also widespread (although later in origin than in Liverpool).$^{30}$ The extent of Walker's distinctive practice is thrown into relief by the experience of another Liverpool company, Bryant \& Ravenscroft. This company was formed in 1874 when Henshall Ravenscroft, a licensed victualler, joined his father in law, a brewer, in partnership. In his bankruptcy hearing in 1887 , Ravenscroft argued that he had joined simply to be his father in law's outdoor manager and so had had no sight of the books. However, it was also revealed that

From 1882 to August, 1886, no cash book was kept, and the cash was never balanced in any way. There was no proper record of the money received by the bankrupt from his numerous houses. There was no account of the goods

${ }^{25}$ DRO Walker-Okeover Papers, D1849, Box 3852/3 Bundle 9, estate of Andrew Barclay Walker, codicil of 16 May 1870

${ }^{26}$ DRO Walker-Okeover Papers, D1849, Box 3852/3 Bundle 9, estate of Andrew Barclay Walker, 12 Jan. 1880,4 Jan. 1883.

27 DRO, D1849 Box 3852 Bundle 8 Private incoming correspondence of Major Walker 1867-81, John Price to Andrew Walker, 26 July 1873.

${ }^{28}$ See, for example, LRO, Peter Walker \& Son, 380PWK/2/1/12a Statements for Canning Place Vaults, 1858-66; 380PWK/2/10a-j Bundle of ms statements; 380/1/4/12, Papers of David Walker; 380PWK/1/4/15, Papers of David Walker.

29 See the detailed account given for a later period in Peter Walker \& Son, Walker's Warrington Ales.

${ }^{30}$ Alistair Mutch, 'Manchester and Liverpool public houses compared, 1840-1914', vol. 12 (2003), pp. 22-9. 
purchased by the bankrupt, nor any account of the drawings of himself or his late partner. The bankrupt never ascertained his financial position at any time during the partnership. ${ }^{31}$

The focus on detailed record keeping, reporting and managerial accountability was not an inevitable product of business conditions in the city. Of course, that Walker was in the forefront of such practices is no evidence of any particularly Scottish connection. However, there is some further suggestive evidence in his involvement with the Glamorgan Coal Company. Again, evidence for this is scattered through the surviving papers, is fragmentary and cannot be supported with material elsewhere, but it does indicate some intriguing parallels. The Llwynypia Colliery of the Glamorgan Coal Company was known locally in the nineteenth century as the 'Scotch Colliery'. ${ }^{32}$ This was because of the origins of the majority of both the managers and owners of the company. This grouping has variously been described as composed of 'Scottish gentry' or 'Liverpool based Scots', but a closer exploration based on Walker's papers and other sources suggests that these descriptions are partial and misleading. ${ }^{33}$ This was a firmly Scottish affair, based on two inter-related Edinburgh families, and on the related families of Walker and the mining engineer Archibald Hood.

The Edinburgh families were those of Campbell and Mitchell-Innes. Both Archibald Campbell and Gilbert Mitchell-Innes had, according to Davies and Hailey, interests in South Wales mining before $1860 . .^{3+}$ Archibald Campbell was the son of a Midlothian sugar merchant who in the 1850 s married Barbara Ann McPherson, daughter of the merchant James McPherson. Her sister, Amelia, married the Edinburgh-based 'gentleman' Gilbert Mitchell-Innes in 1851, thus providing a tie between the two families, a tie seen in the naming by Archibald of Gilbert as an executor in his will of $1869 .{ }^{35}$ Archibald took up 2,000 of the initial 12,100 shares in the company on foundation in 1862, with his brother, John, taking a further 100 shares. ${ }^{36}$ This connection might be why Morris and Williams locate Campbell and Mitchell-Innes as being 'of Liverpool', for John had moved there from Glasgow. ${ }^{37}$ At the time of the foundation of the company he was an insurance broker in the Liverpool partnership of Cambell and Cross. The earliest

31 'H. Ravenscroft, Brewer, Liverpool', Brewers Journal, 15 Aug. 1887, p. 383.

32 J. Davies and C. P. Hailey, 'The Glamorgan Coal Company and Lysberg Ltd', in The South Wales Coal Ammal for 1914 (Cardiff, 1914), p. 1.

${ }^{33}$ R. Walters, 'Capital formation in the South Wales coal industry 1840-1914', Welsh History Review, 10(1) (1980), p. 74; A. Blyth, From Rosewell to the Rhondda: the Story of Archibald Hood, A Great Scottish Mining Engineer (Midlothian, 1994), p. 14.

${ }^{34}$ Davies and Hailey, 'Glamorgan Coal Company', p. 1.

35 (N)ational (A)rchives of (S)cotland, SC70/4/118, Will of Archibald Campbell, 21 April 1863, accessed via http://www.scotrishdocuments.com/

${ }^{36}$ Public Record Office, BT31/609, Glamorgan Coal Company, Memorandum of Association, 23 Jan. 1862.

${ }^{37}$ Morris and Williams, South Wales Coal, p. 142. 
date for this partnership seems to have been in 1859, and John was living in a rather exclusive part of Liverpool in 1861 , but the partnership disappears by $1868 .^{38} \mathrm{John}$ has moved and, significantly, has been removed as an executor from his brother's will. ${ }^{39}$ His holding in the company appears, from an entry in private ledgers, to have been assumed by Andrew Barclay Walker but this Liverpool connection, which was to be so important, appears much later. ${ }^{+0}$ The company was predominantly a Scottish firm from its inception, with offices in Edinburgh. ${ }^{+1}$

Little detail of Archibald seems to be available. He spent his married life with Barbara at Lethen House near Nairn, moving following her death in childbirth in 1861 to Park House in Aberdeenshire. ${ }^{+2}$ He died in Edinburgh in 1869 , his will and inventory indicating interests in ship owning in conjunction with other members of his families, but his holding in the Glamorgan Coal Company was the most significant investment. ${ }^{43}$ His will does, however, suggest that he was a devout member of the Free Presbyterian church, leaving as it does bequests to related missionary societies. Rather more, however, is known of the Mitchell-Innes family. Gilbert, with 3,000 shares, was the prime mover in the financing of the Glamorgan Coal Company, but his brothers Norman and William both took 2,500 each. They were the sons of William Mitchell-Innes, cashier of the Royal Bank of Scotland from 1816 to 1825 and subsequently an ordinary director until $1859 .^{\text {th }}$ The title of 'cashier' is a little misleading, as the holder was in effect the general manager of the Bank. ${ }^{45}$ This was a role that members of the Mitchell and Innes families played together with the related Simpsons from 1745. William Mitchell united the names of Mitchell and Innes 'having lately succeeded to a large fortune by the death of my relative Miss Innes of Stow' ${ }^{+6}$ This was one connection, subsequently reinforced by various marriages involving not only Gilbert but also his brothers Alexander and Thomas, tieing the family into the important landed family of Lauder of Fountainhall. ${ }^{47}$ The term 'gentry' therefore seems a little inadequate to describe the centrality of this family to networks of power at the heart of the Scottish banking establishment.

${ }^{38}$ Gore's Directory of Liverpool, 1859, p. 49; Census 1861 RG9/2738; Gore's 1878, 1868.

${ }^{39}$ NAS, Will of Archibald Campbell, codicil 7 June 1867; his inventory notes 'Debt of $f^{3052} 2 \mathrm{~s}$ due to deceased by John Campbell, Esq. Liverpool. This debt is considered absolutely bad, but a value of one shilling per pound may be stated'. SC70/1/142, 16 Feb. 1869.

* DRO, D1849 Walker-Okeover papers, Box 3, Bundle 1, statements of account 1869-85, entry for December 1871 .

4) 'The Glamorgan Coal Company have an office in Edinburgh where the shares are transferred' - NAS, SC70/1/142, Inventory of Archibald Campbell, 16 February 1869.

${ }^{42}$ Details from birth and death certificates, General Register Office for Scotland, via Scotland's People, www.scotlandspeople.gov.uk

43 Scotsman, 9 Jan. 1869 , p. 8.

it N. Munro, History of the Royal Bank of Scotland 1727-1927 (Edinburgh, 1928), p. 248.

t5 Munro, Royal Bank, p. 249.

t6 Munro, Royal Bank, p. 217.

${ }^{47}$ Gregory Lauder-Frost, Summary of the ancestry \& family of Lauder of Fountainhall', http://www.electricscotland.com/webclans/htol/lauder8.htm, accessed 15 Nov. 2002. 
The Campbell family interests in 1879 were substantially represented by those still held by Archibald's trustees, but the Mitchell-Innes family continued with their holdings. Davies and Hailey note E. A. Mitchell-Innes as a director of the Glamorgan Coal Company in $1914 .^{48}$ Whilst this is beyond the main period of this article, it is noticeable that when the company was reconstructed in 1892 its annual meetings were to be held in Edinburgh. ${ }^{49}$ This represents not only the continuing importance of the Mitchell-Innes family as shareholders, but also the centrality of the mining engineer and coal owner, Archibald Hood. Hood was the son of a colliery foreman who studied mining engineering whilst working as an engine minder. He was an early advocate of mining education, but a stern critic of those who did not share his own thirst for hard work and education. ${ }^{50}$ From his origins near Kilmarnock, Hood initially worked as chief mineral agent to the ironmasters Dunlop and Wilson, during which period he married the daughter of William Walker, coal owner of Auchinleck. In 1856 he took on the lease of Whitehill Colliery in Rosewell, Midlothian. His success with this mine led to the formation in 1890 of the Lothian Coal Company, a merger of his interests with those of the Marquess of Lothian. In 1860, however, he had been commissioned by Campbell and Mitchell-Innes to survey potential mining opportunities in South Wales. It was Hood, according to Blyth, who persuaded the two investors to turn their attention to the Rhondda. ${ }^{51}$ Hood took 1000 shares in the new enterprise and gradually increased his involvement in the company. The substantial nature of this involvement can be seen in his decision to move to Cardiff in 1867 and he became a figure of considerable importance and renown in the South Wales coal industry, receiving widespread tributes from all sections of the industry on his death in Cardiff in 1902. ${ }^{52}$

William Walker was the uncle of Andrew Barclay Walker, but Hood's connections with the family ran deeper. Not only was he an executor, with his wife, of his father-in-law's will (under which his son, William Walker Hood, inherited William's Ballochmyle Colliery) but he was also executor for Peter Walker and his brother Robert, in whose will he is described as 'my friend'. ${ }^{53} \mathrm{He}$ shared both duties with Andrew Barclay, who in turn named him as executor of his own will

${ }^{48}$ Davies and Hailey, Ammual, p. 16.

49 DRO, D1849/1/1-3, Letter Book of Sir Andrew Barclay Walker, E. G. Slatter to John Hughes, 7 Jan. 1893.

${ }^{50}$ M. S. Cotterill, Newbattle Collieries - The Nineteenth Century Background. Essays concerning Midlothian coal mines at Newbattle, Whitehill, Polton and Eldin prior to their acquisition in 1890 by the Lothian Coal Company. Scottish Mining Museum Research Paper number 2, June 1983. (Cotterill has Hood as acting in connection with the Glamorgan Coal Company on behalf of 'a consortium of Scottish capitalists' - p. 135.)

${ }^{31}$ Blyth, From Rosewell, p. 15.

52 Blyth, From Rosewell, p. 27.

53 NAS, SC6/46/7, Trust Disposition and Deed of Settlement of William Walker, 13 Aug. 1871; DRO D1849 Box 3852/2, bundle 19, Will of Peter Walker of Balrazzie, Ayr and residing at Saint Lawrence House, Ayr, 29 Nov. 1879; Box 3852/2, bundle 10, estate of Robert Walker. 
of 1865 , together with his uncle David Walker, 'Colliery Viewer' of St Helens. ${ }^{54}$ Hood continues in this position in a later will of 1873 , but he is replaced in 1880 by English landowners, perhaps marking Walker's own shift into English landed ranks. ${ }^{35}$ However, it is clear that Hood was tightly connected with the Walker family at a personal level and shared considerable overlapping interests in both colliery management and ownership. One can assume that he was the motive force in getting Andrew Barclay to invest in the Glamorgan Coal Company and, possibly, to take some interest in its operation. In 1868 he wrote to 'my dear Walker' reporting that he had recently met Archibald Campbell and Gilbert Mitchell-Innes and that "they both expressed a wish that you would go \& visit the works \& you know my wish on the subject' ${ }^{56}$

Whilst Walker's interest in the company seems to have been primarily as a substantial investor, surviving papers indicate that he did receive a substantial amount of information. Included amongst his papers are fortnightly and monthly reports from local managers. The fortnightly reports were on printed pro-formas for each colliery and showed total sales and costs per vein. For each vein costs were split between hewing, underground on-cost and surface on-cost, the latter two at a rate per ton. The existence of such reports indicates a supporting cost collection system and a considerable degree of prior consideration of the information that might be required. These reports are supplemented by monthly reports by the local managers, which survive for September, October and December 1867. These suggest that Hood was the prime mover in the management of the collieries. In September, for example, the manager, an H. Begg, reported

From a suggestion of Mr Hood, I am endeavouring to change the system of working and am happy to state have so far succeeded provided that our men may be allowed to continue as they have arranged. They will be quite willing if they are not interfered with by their fellow workmen in other Collieries. If I succeed it will be a great saving to the Company and likewise be the means of establishing a system of working that has not been formerly adopted in South Wales. ${ }^{57}$

However, in the following month he was obliged to comment

We made an attempt to change the system of working in this vein. I had no doubt at the time but that we would succeed, but in consequence of repeated threats from workmen in other collieries, our men considered themselves in danger and refused to work on any other system but what was customary in the country. ${ }^{58}$

${ }^{54}$ DRO, D1849, Box 3852/3 bundle 9, Estate of Andrew Barclay Walker, 1865.

35 DRO, D1849, Box 3852/3 bundle 9, Estate of Andrew Barclay Walker, 1873, 1880.

${ }_{56}^{5}$ LRO, PWK 380/1/1/6, correspondence of Andrew Barclay Walker, Hood to Walker, 1 Feb. 1868.

37 LRO, 380PWK/1/1/3, Glamorgan Coal Company, manager's report, Sept. 1867.

${ }^{58}$ LRO, 380PWK/1/1/3, Glamorgan Coal Company, manager's report, Oct. 1867. 
Unfortunately, these glimpses of colliery operation are tantalisingly brief. They also report on sales, on progress with sinking shafts and building coke ovens, and on the success of the competition run for prize gardens. However, their very existence is suggestive of the way in which it was more than capital which flowed from Scotland. It was also managerial practice and personnel. Hood was known in his Lothian operations for recruiting his trusted managers from his native Ayrshire. ${ }^{59}$ Whilst we have no details of ' $\mathrm{H}$. Begg' (although the name suggests Scottish origins), we do know that Robert Duncan worked with Hood at Rutherglen, moved to Llwynypia and became company secretary in $1871 .^{60}$ We have also noted the provision at Llwynypia of houses with gardens and other facilities, a practice at odds with that generally found in South Wales. Hood was also known for such paternalistic practices in Lothian, although on a more extensive scale (possibly because of his partnership with the Marquis of Lothian). Newtongrange was laid out as a model community, but a key feature of Hood's regime was a focus on control through not only housing but also through the provision of leisure facilities. ${ }^{61}$ What is of particular interest for our account is the parallel between the detailed reporting found in both cases. Now, whether this is a specifically coal industry practice or one drawn from Scottish practice more generally is not clear, but it certainly seems that there is a common focus on control being exercised through both detailed financial control and through more qualitative reports.

Some further evidence is suggestive of the Scottish roots of this focus on accountability through financial reporting. In 1810 the Hudson Bay Company undertook a radical revision of its accounting and management practices. This enabled it to hold specific organisational members directly accountable and enabled the analysis of profitability by unit in a fashion that anticipated changes made elsewhere in the late nineteenth century. The originator of this innovation was a Scot, Andrew Wedderburn. At the same time Edward Ellice, born in London of Scots parents and educated at Marishal College, Aberdeen, was introducing similar practices to the competing North West Company. ${ }^{62}$ Such organisational practices mirror the very early emphasis on costing in the eighteenth century texts on accounting produced in Scotland. Mepham reviews the work of five Scottish authors and points to the longevity and influence of their contributions. ${ }^{63} \mathrm{He}$ sets this work in the context of developments in the printing and publishing industry,

59 A. Campbell, The Scottish Miners 1874-1939. Volume One: Industry, Work and Community (Aldershot, 2000), p. 264.

Davies and Hailey, Anmual, p. 6.

'il Campbell, Scottish Miners, p. 263.

i2 G. Spraakman, 'A critique of Milgrom and Roberts' treatment of incentives vs. bureaucratic controls in the British North American fur trade', Journal of Managentent Accounting Research, vol. 14 (2002). Further details were supplied in an unpublished paper, G. Spraakman, 'The transfer of management accounting practices from London counting houses to the British North American fur trade', paper at 16th Accounting Business and Finance History Conference, Cardiff, 2003.

${ }^{63}$ M. J. Mepham, 'The Scottish Enlightenment and the development of accounting', in R, H. Parker and B. S. Yamey (eds), Accomming History: Some British Contributions (Oxford, 1994). 
and pays attention to the content of education, pointing out that bookkeeping was widely taught in the grammar schools from 1750 . However, the major focus is on the broader ideas of the Enlightenment, a focus on the history of ideas which is also to be found in Marshall's discussion of the links between the forms of religion adopted in Scotland and the rise of business practice. ${ }^{64}$ We have already noted Camic's reservations about such an approach and the one Enlightenment figure who has anything to say directly about management, Adam Smith, is distinctly cool about management, His emphasis, based on perceptions of events at the British Linen Company, was on the need for the personal involvement of owners. ${ }^{65}$ At best, the Enlightenment provided an emphasis on systematic inquiry based on empirical observation. ${ }^{66}$ However, a more fruitful line of inquiry might be that the particular forms of organisation employed in Scottish Presbyterianism provided a set of practices that was conducive to a focus on managerial accountability through detailed record keeping. Accordingly, we turn to a consideration of the histories of the church in Scotland.

\section{Organising Religion: Scotland and England}

In common with work on other churches, there is relatively little work on the organisational practices of the Scottish Presbyterian churches, with the focus, understandably, being on matters of doctrine and membership. ${ }^{67}$ In recent years we have had the magisterial work of Margo Todd, although this is concerned with the sixteenth and seventeenth centuries. ${ }^{68}$ Her work is particularly valuable in its emphasis on the systematic nature of Scottish church organisation, something which will be thrown into sharp relief when we contrast it with English practice later. However, her focus on the kirk session and the impact that this has on takenfor-granted approaches is nicely echoed in a review of a modern book on the organisation of the Church of Scotland. McHugh notes that

The whole system of courts, with lay representation from bottom to top, including therefore secular experience and expertise at every level of church life, makes for business-like completeness (a Calvinist carefulness?) in the returns made to the General Assembly. Since the data are there, one can have confidence in the analysis in a way that is not possible in some other Christian traditions. ${ }^{69}$

ot Marshall, Presbyteries and profits.

is Alastair J. Durie, The Scottish Linen Industry in the Eighteenth Century (Edinburgh, 1979), p. 140.

${ }^{60}$ Andrew S. Skinner, A System of Social Science: Papers Relating to Adam Stmith (Oxford, 1979); Whatley, Scottish Society, p. 121.

${ }^{67}$ C. G. Brown, Religion and Society in Scotland since 1707 (Edinburgh, 1997); A. L. Drummond and J. Bulloch, The Scottish Clurrch 1688-1843: The Age of the Moderates (Edinburgh, 1973); N. MacDougall (ed.), Church, Politics and Society: Scotland 1408-1929 (Edinburgh, 1983).

${ }^{68}$ Margo Todd, The Culture of Protestantism in Early Modern Scotland (New Haven, 2002).

"9 F. McHugh, 'Review of The Church of Scotland: An Econonic Survey', The Economic Journal, vol. 91 (1981), p. 583. 
The central institutions here are the Kirk Session and the elder. ${ }^{70}$ These, argued Henderson, had their origins in the need for discipline and were subsequently supported by appeal to scriptural authority. ${ }^{71}$ The important consequences for our discussion were the widespread participation of laymen in the affairs of the church and the focus of that participation on both accountability and record keeping. This involvement of laymen, especially in urban areas, may have formed church governance practices in the image of existing commercial practice. ${ }^{72}$ However, it is also worth noting, especially in the context of our later comparison with English practice, Todd's observation that powerful nobles and burgesses had need of the discipline of the kirk session in a country with weak central government. ${ }^{73}$ She contrasts this to the effective system of justices of the peace that had been developed in England. Whatever the precise nature of its origins, a key focus of the Presbyterian system as implemented in Scotland was the emphasis on accountability. Clearly much of this was on the discipline of ordinary members of the congregation, but it is as well to remember that accountability applied to both minister and elders. Graham reproduces an account of a Presbyterial visitation at Ordiquill in 1717:

The minister having preached his ordinary, Matt. xxviii. 5, to consider doctrine. The minister removed, elders and heads of families called. Interrogated if the minister had a gospel walk, if he kept much at home and gave attendance to reading and prayer, if he preached sound doctrine and studied to be powerful in his ministrations, if he did visit families as need is. ${ }^{74}$

As Henderson points out, the minister then got his opportunity to report on his elders. In the Synod of Aberdeen in 1674 the investigation, having considered the minister and the elders, then continued further

Heritors, elders and heads of families with the minister are tried as to the condition of the parish; the mortifications; the educational facilities, the character of the schoolmaster, and whether he thrashes children for lying, swearing, disobedience to parents; the fabric of the church, the stipend, the utensils for Communion; the prevailing faults of the parishioners, the state of church attendance and the example shown by those responsible for the spiritual well-being of the parish. ${ }^{75}$

${ }^{70}$ J. Kirk, "“The Politics of the Best Reformed Kirks": Scottish achievements and English aspirations in church government after the Reformation. A revision article', Scottish Historical Review, vol. LIX (1980).

${ }^{7}$ G. D. Henderson, The Scottish Ruling Elder (London, 1935), p. 19.

12 Norman MacDougall (ed.), Church, Politics and Society: Scotland 1408-1929 (Edinburgh, 1983).

3 Todd, Culture of Protestantism, p. 408.

${ }_{75}^{7}$ H. G. Graham, The Social Life of Scotland in the Eighteenth Century (London, 1969 [1899]), p. 333.

75 Henderson, Ruling Elder, pp. 179-80. 
This detailed tradition of investigation also applied to the practice of Communion. The emphasis on Communion being given only at long intervals to those properly prepared to receive it, placed a considerable emphasis on the role of elders in attesting to the spiritual state of potential communicants. What seems to happen, however, is a move from the direct interrogation of communicants before each session to the compilation of membership rolls, accompanied by the practice of the distribution of tokens (and subsequently cards) to those whose place on the list can be confirmed. In Yester, in 1769, for example, 'the Session met at the manse for prayer and to read over the examine roll as usual before the Sacrament ${ }^{9} .^{76}$ As Todd notes for an earlier period 'good record-keeping is a hallmark of Scottish communion seasons, with lists of those eligible and those who actually appeared at the table routinely compared to ensure that no one had communicated unworthily'. ${ }^{77}$

They were already responsible for the keeping of parish registers, but another important part of their responsibility was provision for the poor. They needed to organise and take part in church collections, and to manage church funds, which might include 'mortifications' (legacies and trusts). Henderson reproduces a budget produced at Yester in 1728 which uses estimates of 'the medium' of income and expenditure to predict a deficit ${ }^{78}$ This also points to the Session's role in lending money to produce interest. The use of 'charge and discharge' accounting in managing these funds represents a degree of continuity with pre-Reformation practice, but exercised in a controlled fashion. In 1774 for example, the kirk session of Rayne, Aberdeenshire, examined the treasurer's accounts and 'diligently compared the same Article by Article with the Accounts of Charge and Discharge kept by their own Clerk ${ }^{79}$ These aspects of financial management are supported for a much later period by one of the few works to examine organisational aspects of church life, Brown's examination of pew renting in Glasgow. ${ }^{80}$ Not only is this for a later period, but also the management was under control of the town council rather than lay elders, but his findings are still suggestive. His study depended on the survival of records which enabled the Ecclesiastical Department to carry out analyses of the distribution of seats and their financial yield. What is important here is the existence of a form of governance which not only engendered 'business like' practices in church life but might also have formed those practices. Marshall, for example, gives some details of the organisational arrangements obtaining in the Newmills' Cloth Manufactory:

There were at least four general meetings each year at which company policy was decided and accounts were examined, all decisions being arrived at on the basis of binding majority vote. At the meeting in May five members were

${ }^{76}$ Henderson, Ruling Elder, p. 48.

7 Todd, Culture of Protestantism, p. 77

${ }^{78}$ Henderson, Ruling Elder, p. 85.

${ }^{79}$ NAS, CH2/310/6/1, Kirk Session minutes, Rayne, 1772-1814, 10 Jan. 1774.

${ }^{80} \mathrm{C}$. G. Brown, 'The costs of pew-renting: church management, churchgoing and social class in nineteenth century Glasgow', Journal of Ecclesiastical History, vol. 38 (1987), pp. 347-61. 
elected as 'managers' and, after the first election, two remained in office and three new ones were elected each year. The managers met at least once a week, electing among themselves a 'praeses' (chairman) for each meeting. A quorum of three was necessary for business to proceed. The day to day running of the factory was, however, entirely in the hands of the 'Master', that is (in modern usage), 'paid manager. ${ }^{81}$

Marshall's analysis tends to the exploration of beliefs about the running of business in the context of religious belief, but he, as with other commentators, recognises the difficulty of establishing links between the two.$^{82}$ The exploration of the social practices entailed by religious forms might offer a more fruitful area for exploration. Whilst the number of elders involved in church governance might have fluctuated from parish to parish, it would seem that a large number of Scottish laymen, particularly those who Foster terms the 'second rank leadership' in their localities, were exposed to practices which placed an emphasis on accountability. ${ }^{83}$ In this practice all, regardless of social status, could potentially be called to account. Of particular note is the way that elders were used to keep a check on their minister. This sense of being able to hold to account might encourage the use of directly employed managers, as opposed to other more indirect contractual arrangements, such as tenants or agents. Also of interest is the increasing focus on the keeping of records, from communion rolls to the session minutes themselves. What this suggests is exposure to a variety of forms of record keeping which might then be available as models to transfer into business practice.

The distinctiveness of these Scottish practices is thrown into sharper relief if we compare them to English practice. As Todd observes, it was the institution of the kirk session that was the crucial difference between the two countries. In England there was no comparable institution, although it too saw a move away from broader lay involvement in church affairs towards a concentration of administration in the hands of a smaller group. ${ }^{8+}$ In England this administration was in the hands of a range of parish officials, but of most importance were the churchwardens. We need to recognise at this point that the history of this office has been relatively under-researched, with most of the work that exists relating to the sixteenth and seventeenth centuries. ${ }^{85}$ This limited range of work should be

${ }^{81}$ Marshall, Presbyteries, p. 145.

${ }^{82}$ Brown, Religion and Society, p. 178

${ }^{83}$ W. Foster, The Church Before the Covenants: The Clurrch of Scotland 1596-1638 (Edinburgh, 1975), p. 70 .

${ }^{84}$ Eamon Duffy, The Stripping of the Altars: Traditional Religion in England 1400-1580 (New Haven, 1992).

${ }^{85}$ Katherine L. French, Gary G. Gibbs and Beat A. Kúmin, The Parish in English Life 1400-1600 (Manchester, 1997); J. S. Craig, 'Co-operation and initiatives: Elizabethan churchwardens and the parish accounts of Mildenhall', Social History, vol. 18, no. 3 (1993), pp. 357-80; Eric Carlson, 'The origins, function and status of the office of churchwarden, with particular reference to the diocese of Ely', in Margaret Spufford (ed.), The World of Rural Dissenters, 1520-1725 (Cambridge, 1995); Charles Drew, Early Parochial Organisation in England: The Origins of the Office of Churchnarden (London, 1954). 
born in mind in the discussion that follows, which is based on this secondary work plus a small sample of archival material. What this limited range of evidence does, however, indicate is that the ranks of parish officials were dominated in both countries by the 'middling sort', albeit with a somewhat wider social range in Scotland.$^{86}$ However, there were considerable differences in selection, duration and content of office that could be summarised in a personal focus in England as opposed to a systemic focus in Scotland.

Part of the reason why the ranks of churchwardens were dominated by the middling sort was because holders could expect to have to be indebted at some time during their tenure. Litzenberger points out that for Gloucester 'the churchwarden would often be expected to meet a shortfall in parish finances from his own pocket ${ }^{87}$ In the Nottinghamshire parish of Calverton between 1720 and 1787 the churchwardens were more likely to be owed money by the parish than not at the end of their term of office (thirty years out of fifty-five ended in a deficit) ${ }^{88} \mathrm{~A}$ thirty-nine-year period in the parish of West Bridgford in the same county reveals a healthier position for the wardens, with money owing to them in only eight years. ${ }^{39}$ However, this tells us nothing (and the form of accounts will not tell us) about debts incurred during the course of office. The difference between parishes suggests the need for further work, but the two parishes do support a key difference in practice between the two countries. Churchwardens held office on an annual basis, whilst elders were, in theory at least, office holders for life. Whilst this might not always have been the case in practice, Houston finds that $43 \%$ of elders at Tolbooth in Edinburgh between 1690 and 1760 served terms of over three years, and that the tendency over the period was that 'work on the kirk session became the preserve of a core of committed, long-serving men' ${ }^{90}$ Such tendencies approximated much more closely to the ideal laid down in the Second Book of Discipline, and it was one that diverged considerably from the English pattern. ${ }^{91}$ Here, Wrightson and Levine, for example, comment on the emergence of office-holding amongst a limited group, and the emergence of a degree of consecutive office-holding, but it is quite clear that this is firmly in the pattern of annual office- holding. ${ }^{92}$ In West Bridgford, we do indeed find a consistent pattern of the same individuals taking a regular turn at being the churchwarden appointed by the vicar, but there is only one period of consecutive office-holding, in the 1780 s. Of the wardens appointed by the parish, twenty-one individuals hold office

\footnotetext{
${ }^{86}$ Keith Wrightson and David Levine, Poverty and Piety in an English Village: Terling 1525-1700 (New York, 1979), p. 104; R. A. Houston, Social Change in the Age of Enlightenment: Edinburgh, 16601760 (Oxford, 1994), p. 200.

${ }^{87}$ Caroline Litzenberger, 'St Michael's Gloucester, 1540-80: the cost of conformity in sixteenthcentury England', in French, Gibbs and Kumin, Parish in English Life, pp. 230-49.

${ }_{88}$ (N)ottinghamshire (R)ecord (O)ffice, PR 2573 Calverton town book, 1720-87.

${ }^{89}$ NRO, PR 20287, Parish book West Bridgford, 1759-1835.

90 Houston, Social Change, p. 203.

91 Todd, Protestantism, p. 371.

92 Wrightson and Levine, Poverty and Piety, p. 106.
} 
over the thirty-nine years, with the maximum number being four times for one individual. ${ }^{93}$ Calverton shows a similar pattern, with consecutive office-holding being again a feature of the later eighteenth century. ${ }^{94}$

These patterns of office-holding have consequences for the nature of organisational practice. Wrightson and Levine might be able to find evidence of stability and confidence in 'the neatly kept parish books of the later seventeenth century' for Terling, but this is not at all the picture in eighteenth century Nottinghamshire. ${ }^{95}$ The chaotically kept parish book in Calverton reveals an interesting pattern of accounting, indicated in the dates on which accounts are rendered. Whilst most (twenty-nine of the fifty-two for which the date is noted) were recorded in either May or June, there is a spread across the year, with nearly every month being represented. ${ }^{96}$ In most cases, the bare figures of total income and expenditure are given. West Bridgford accounts are given in more detailed form and, in general, in a more disciplined fashion, but they still bear the marks of the form in which they were clearly rendered.That is, an entry which records expenditure of five shillings 'Spent at giveing them up' in West Bridgford in 1760 suggests the essentially oral nature of accounting, following in the tradition established by Duffy. ${ }^{97}$ In 1732 the Calverton parish book notes 'John Coop gave up his Church warding accounts and the town is Indebted to him twelve shillings and ten pence'. ${ }^{98}$ This suggests a form of accounting which is profoundly personal. In such circumstances the notion of budgeting for the following year would simply not be feasible. Not only was there not the detail recorded in the appropriate form on which to draw up estimates for the following year, but there was relatively little continuity of officeholding in order for any budget to be followed through.

The Webbs argued that the eighteenth century saw the emergence of the Select Vestry in many parts of England, in which a smaller group of officials took more of an 'executive' role in parish affairs. ${ }^{99}$ There is little sign of this in the Nottinghamshire parishes. The Calverton parish book notes decisions made in February 1762 'at a Vestry called this Day according to the Antient Custom of the Town'. ${ }^{100}$ This adherence to custom seems to have marked much English local administration, with a variety of offices being filled according to that custom, and filled in a personal capacity. By contrast, the Scottish practice is much more systematic.

${ }^{93}$ NRO, PR 20287, Parish book West Bridgford, 1759-1835.

94 NRO, PR 2573, Calverton town book, 1720-87.

${ }^{45}$ Wrightson and Levine, Poverty and Piety, p. 183.

${ }^{96}$ NRO, PR 2573, Calverton town book, 1720-87: the most popular other times of the year to render accounts were December and January, with five each; only March and September had no accounts rendered.

${ }^{97}$ NRO, PR 20287, Parish book West Bridgford, 1759-1835, 1760; E. Duffy, The Voices of Morebath: Reformation and Rebellion in an English Village (New Haven, 2001).

${ }^{48}$ NRO, PR 2573, Calverton town book, 1720-87, 2 Dec. 1732.

"9 Sidney and Beatrice Webb, The Development of English Local Government 1689-1835 (London, 1963), pp. 31-2.

${ }^{100}$ NRO, PR 2573, Calverton town book, 1720-87, 12 Feb. 1752. 
This is related to the establishment of the kirk session as a clearly defined group of individuals with definite responsibilities. Out of such definitions could arise practices of record keeping, financial projection and allocation of responsibility that could form the basis for managerial practice.

\section{Conclusion}

The comparison between the two countries suggests that in Scotland organisational practices existed which could foster an emphasis on detailed record keeping. The formation of the kirk session as an 'executive committee' with members holding office for long periods would make it feasible to plan ahead. In turn, habits of record keeping were formed by the need to monitor communicants, a practice which could then transfer over into other areas of activity. By contrast, the English system was a much more personal one, with officeholding being restricted in duration and the burdens of office being thrown onto individuals. In these circumstances, it would be difficult for any systematic process of record keeping to emerge as a challenge to the dictates of custom. The Scottish practice of accountability, discipline and record keeping could therefore form a resource which could be drawn upon in other areas of activity, notably in commercial life. The examples presented above suggest a distinctively Scottish contribution to the challenges of managing large organisations.

Of course, the account presented has been based on a relatively limited range of sources. A number of further avenues for research can be suggested. One night be further investigation into the religious background of key actors such as Andrew Barclay Walker. However, this is likely to be of limited value. Given that the emphasis above has been on the taken-for-granted nature of organising, then such resources become available to those who have been brought up in particular contexts, whether or not they have directly held office. Of more interest would be work on fleshing out the organisational practices outlined.The Scottish examples are largely taken from Henderson's work which is now of considerable age and in which the records examined were not selected on any sort of systematic basis. An exploration of the copious collections of kirk sessions minutes looking for evidence of organisational practice in the eighteenth century that follows in the footsteps of Todd's work might be of considerable value. The work in England is even more undeveloped and an exploration of a representative sample of accounts with a focus on the issues raised by the initial analysis of the records for Calverton and West Bridgford would help in testing the assertions made above about English practice. Consideration of other forms of activity, such as that of urban overseers of the poor, might also give a fuller picture of the practices available to those seeking to run larger commercial enterprises. This might help to determine whether the issue is that of Scottish administrative practice or whether it is a matter of the greater involvement of laymen in Scottish affairs giving rise to a wider network for knowledge diffusion. Finally, the focus in the above has been 
on the established churches; a similar approach examining organisational practice in other denominations might also be useful. Such work would give us better material on which to assess the resources available to those seeking to develop new managerial practice and so would help to fill out the social and economic histories of both countries.

\section{Acknowledgements}

I should like to thank staff in the following institutions for help in locating and accessing documents: Warrington Central Library for the history of Peter Walker \& Son published in 1896; Liverpool Record Office for the papers of Peter Walker \& Son, the Liverpool Licensing Registers and many other sources; Derbyshire Record Office, Matlock, for the Walker-Okeover papers; Nottinghamshire Record Office for churchwardens' accounts; National Archives of Scotland for kirk session records. My thanks also to participants at the 16th Accounting, Finance and Business History conference at Cardiff, and especially Gary Spraakman, for useful pointers to other Scots involved in the development of management practice. Research was supported by ESRC Award number R000223773. 
Copyright of Journal of Scottish Historical Studies is the property of Edinburgh University Press. The copyright in an individual article may be maintained by the author in certain cases. Content may not be copied or emailed to multiple sites or posted to a listserv without the copyright holder's express written permission. However, users may print, download, or email articles for individual use. 
Copyright of Journal of Scottish Historical Studies is the property of Edinburgh University Press and its content may not be copied or emailed to multiple sites or posted to a listserv without the copyright holder's express written permission. However, users may print, download, or email articles for individual use. 